\title{
Hydrological Modelling of Sediment Yield of Agr0 -Forestry Watershed
}

\author{
B. R. Joshi, S. M. Yadav, B. K. Samtani
}

\begin{abstract}
For this analysis, the Manot sub-basin region of Upper Narmada Basin located in Madhya Pradesh, India, is designated for estimation of runoff, sediment load, sediment concentration and sediment yield using SWAT. The model was implemented during 1989 and 2008. NBSSLUP soil data, Digital Elevation Model (DEM), slope, Land use Ground cover (LULC) and climate records of temperature and rainfall were used as inputs for the Manot Gauge Station. The forecasted model discharge was estimated statistically and compared the real daily flow data from 1989 to 2008, which corresponds to a major number. The R2 value (coefficient of determination) for discharge, sediment concentration, sediment load and sediment yield values for the period 1989 to 2008 were found to be $0.95,0.94,0.96$ and 0.96 respectively. RMSE for discharge, sediment concentration and sediment yield were found to be $0.32,0.27$ and 0.17 , respectively. The expected sediment load at the Manot Gauge Station for the duration (1989-2008) is 6670918 tons per year and the observed sediment load is 6255565 tons per year. Simulated sediment load and measured sediment load at the Manot Gauge Station are 14.13 tons / year / hectare and 15.02 tons / year / hectare, respectively. Predicted sediment concentrations and measured sediment concentrations at the Manot gauging station were found to be 8.81 ppm and $7.46 \mathrm{ppm}$, respectively. Similarly, the expected and observed Sediment Yield was $1.513 \mathrm{~mm}$ and $1.704 \mathrm{~mm}$ respectively.
\end{abstract}

Keywords: SWAT, Hydrological modeling, Sediment Concentration, Sediment Yield.

\section{INTRODUCTION}

The natural ecosystem consists of the topsoil, stream and plant surroundings required for the continued survival and comfort of humankind (1). In the past, the Earth system has been troubled by over-exploration of the ecosystem at the peak of requirements due to industrial growth, etc. Deforestation resulting in bare soil surface results in soil erosion (2). The soil that has been eroded is deposited in the reservoir, thereby reducing its ability. Increased soil erosion,

Revised Manuscript Received on May 15, 2020.

* Correspondence Author

B. R. Joshi1*, Research Scholar, S. V. N. I. T., Surat, Gujarat, India, 395007; Email: bankim.joshi@gmail.com

Dr. S. M. Yadav, Professor, S. V. N. I. T., Surat, Gujarat, India, 395007; E-mail: shivnam27@gmail.com

Dr. B. K. Samtani, Professor, S. V. N. I. T., Surat, Gujarat, India, 395007; E-mail: samtanibk1956@gmail.com

(C) The Authors. Published by Blue Eyes Intelligence Engineering and Sciences Publication (BEIESP). This is an open access article under the CC BY-NC-ND license (http://creativecommons.org/licenses/by-nc-nd/4.0/) which is caused by human activity, is correlated with soil productivity by eliminating the active topsoil and reducing the lifetime of the storage reservoir by sediment particles (3). Sediment yield simulation concerned concentration but a lack of sources and a valid method for estimating it are some of the obstacles in this trend (4). Collection of sediment discharge data during the year and regular basin investigation data (5) are key challenges in predicting sediment yield rates at the basin level (6). SWAT was effectively used by scientists for distributed hydrologic simulation and managing waterbodies in the catchment. (7) across variety of environment and topography parameters. It shows that SWAT can provide sufficient hydrologic simulation associated with weather change in basins. (8). One of the key difficulties of the dam technique is the accumulation of sediment in its reservoir, which results in a decrease in its storage capacity (9). This affects the different structural components of the dam (10). The storage potential of dams is of considerable significance in regions where water shortages exist (11). Topsoil particles removed from a basin could not be transported up to opening of basin due to their trapping in the upstream areas (12). Research has shown that storage reservoirs reduce their capacity effectively by deposition of sediment particles to $1-2$ $\%$ annually (13). Sedimentation continues to be one of the biggest concerns of the river environment. Sediment is a contaminant that impairs most of the streams in the soil erosion model (14) that defined the deposition, settlement and movement of soil elements by precipitation and discharged water from its point of source to the watershed outlet (15). Sediment yield amount is an integrated measure of destruction, conveyance, and settling processes (16). The sediment system in the basin is not solitary sediment yield (17) but also counting sediment movement with the rivers (18).

Water associated action that occurs in one part of a stream catchment may have an effect on the other part (19). Analysis of sedimentation is needed for the study of the storage capacity of the reservoir (20). This involves the collection of water samples from measuring stations on a regular basis (21). Sediment gauging networks provide the vital data needed to create a precise sediment budget defined for four major sediment exchanges for a large, physically efficient river (22).

In this analysis, the SWAT model is used to estimate the soil loss prediction of the Manot basin of Upper Narmada River. 
The area selected for this analysis (Fig.1) is part of the upper Narmada basin from the sources of the Narmada River (Amarkantak) to the Manot Gauge Site situated on the main Narmada River in central India and the fifth longest river in India. Manot is situated at $80^{\circ} 31^{\prime}$ longitude and $22^{\circ} 44^{\prime}$ latitude at $475 \mathrm{~m}$ above Sea Level with a total surface area of 4467 sq. km.

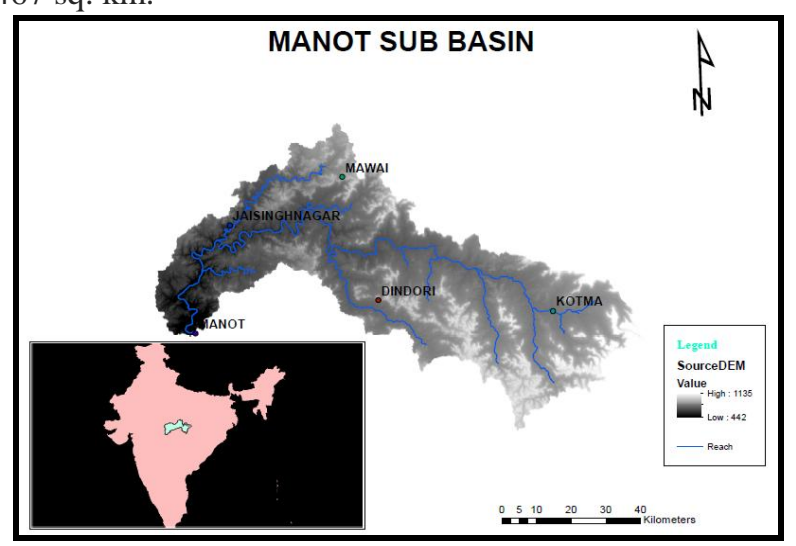

Figure 1 Manot Sub Basin of Upper Narmada River basin

The specifics of the Manot gauge stations are shown in Table 1 which is located at 22o 44 'and 80 o 30' latitude and longitude.

\begin{tabular}{|c|c|c|c|c|}
\hline $\begin{array}{l}\text { STATION } \\
\text { NAME }\end{array}$ & $\begin{array}{c}\text { RIVER/ } \\
\text { TRIBUTARY }\end{array}$ & TYPE & $\begin{array}{c}\text { LENGTH } \\
\text { OF } \\
\text { RIVER } \\
\text { (KM.) }\end{array}$ & $\begin{array}{c}\text { DRAINA } \\
\text { GE } \\
\text { AREA } \\
\text { (SQ. } \\
\text { KM.) }\end{array}$ \\
\hline Manot & Narmada river & GDSQ & 265 & 4667 \\
\hline
\end{tabular}

The specifics of the Manot gauge stations are shown in

Table 1 which is located at 22o 44 'and 800 30' latitude and longitude.

Table 2 Details of Rain gauge station of Manot Basin

\begin{tabular}{|c|c|c|c|}
\hline $\begin{array}{c}\text { STATION } \\
\text { NAME }\end{array}$ & LATITUDE & LONGITUDE & $\begin{array}{c}\text { TYPES OF } \\
\text { STATION }\end{array}$ \\
\hline Manot & $22^{0} 44^{\prime} 09^{\prime \prime}$ & $80^{0} 30^{\prime} 44^{\prime \prime}$ & GDSQ \\
\hline Jaysingnagar & $22^{0} 37^{\prime} 06^{\prime \prime}$ & $80^{0} 34^{\prime} 45^{\prime \prime}$ & Rain Gauge \\
\hline Mawai & $22^{0} 30^{\prime} 00^{\prime \prime}$ & $81^{0} 04^{\prime} 15^{\prime \prime}$ & Rain Gauge \\
\hline Dindori & $22^{\circ} 56^{\prime} 52^{\prime \prime}$ & $81^{\circ} 04^{\prime} 34^{\prime}$, & Rain Gauge \\
\hline Kotma & $23^{\circ} 12^{\prime} 00^{\prime \prime}$ & $82^{\circ} 01^{\prime} 00^{\prime \prime}$ & Rain Gauge \\
\hline
\end{tabular}

\section{DATA COLLECTION}

The data required for catchment hydrology modeling are hydro-meteorological, geomorphological, agricultural, geological and hydrological. The SWAT model requires different input types, such as soil classification, LULC, topography, atmosphere, etc. Input data were obtained from various sources, such as soil data from NBSSULP, LULC images from L8OLI / TIRS, climate data like precipitation, temperature data were obtained from CWC, IMD, and NCA.

The total number of observation sites in the area is shown in Figure 2. Manot is the lower boundary of the Upper Narmada Basin. The annual / seasonal sediment yield in mm is the average soil height in $\mathrm{mm}$ of the reservoir equal to the annual suspended sediment runoff measured at the gauging station. It is computed using the relation. (Hydrological Data Book, CWC 2009) given in equation 1.
Total Sediment Yield $=\frac{\text { Total Sugpended Sediment Load } x 1400}{\text { Total Catchment Area }(\mathrm{Km})^{2}}$

\section{DATA ANALYSIS}

\section{A. Precipitation}

Data were collected from various sources have many missing data such as daily data or station data for a particular period which can be interpolated from various tools. Precipitation has many missing values that were taken into account and the percentage of missing data was find out using the Thiessen Polygon method and comparison method. The comparison method (equation number 2) was used when the yearly precipitation at any station changes from the interpolation station by greater than $10 \%$

$$
\mathrm{Pm}=\frac{1}{n} \sum_{i=1}^{n}\left(\frac{\mathrm{Nm}}{\mathrm{Ni}}\right) \mathrm{Pi}
$$

\section{HYDRO METEOROLOGICAL SITES IN MANOT SUB BASIN}

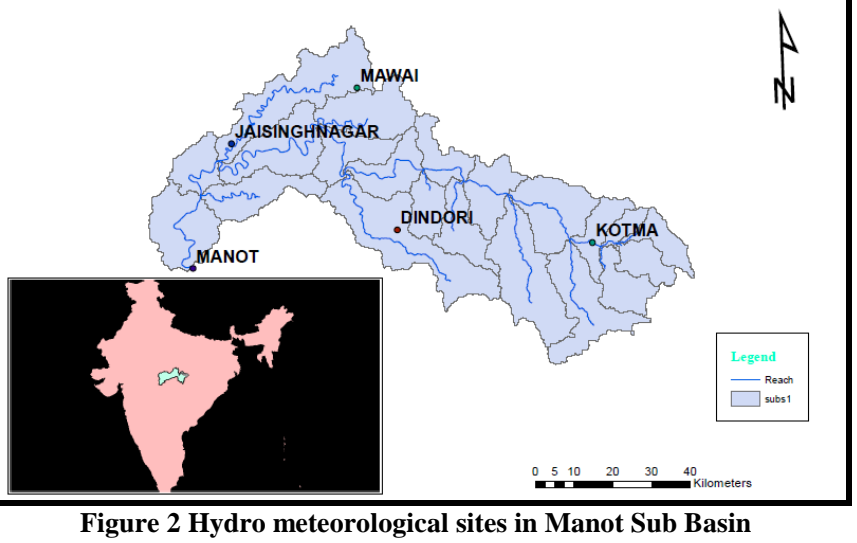

\section{B. Discharge}

Missing data of discharge was found by using the interpolation method using the best-fit curve method from available rainfall data.

\section{Bad data rejection}

The bad data was removed using Chauvenet's criteria. in which the expected number of records at least as bad as the expected record less than $1 / 2$, then the expected measurement should be rejected. According to this, each value has a $50 \%$ chance of continued existence. (Figure 3)

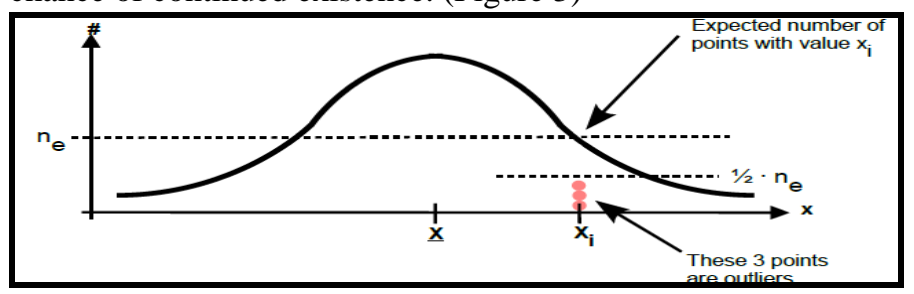

Figure 3 Chauvenet's Criteria for Bad Data Rejection

\section{SWAT Input Layers}

SWAT model needs various input records such s soil, climate, land use, topography, etc. Data were composed of many sources as described below and various procedures have been carried out.

Published By:

Blue Eyes Intelligence Engineering

\& Sciences Publication

(C) Copyriaht: All riahts reserved.

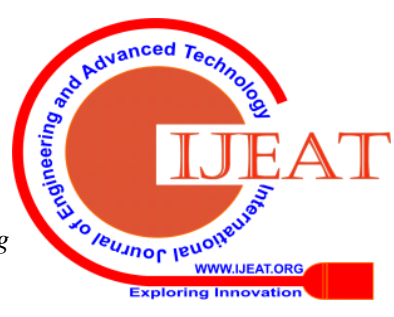




\section{E. Digital Elevation Model (DEM)}

DEM was obtained from the SRTM (Shuttle Radar Topography Mission) with a resolution of 30x $30 \mathrm{~m}$. This means that every pixel of the DEM has a surface area of 900 $\mathrm{m} 2$. Figure 4 shows the DEM for the area.

\section{F. Land Use Land Cover}

The images from satellite IRS L8OLI/TIRS (resolution 30 m) was geo-referenced with related toposheets of SRTM. Supervised classification was done using the maximum likelihood algorithm. The SWAT view of the LULC map for the Manot sub-basin of the upper Narmada Basin is shown in Figure 4 . The main region of the catchment covered in forest and grassland areas. The proportion covered in the Manot sub-basin forest (45.73\%), agriculture and grassland (36.50\%), urban residential (9.26\%), and water (8.50\%).

\section{G. Soil Classification}

The soil map and its belongings for the basin were collected from the NBSSLUP, digitized and graded into different soil groups and used in the analysis. Soils were categorized into four major groups, such as group A, group B, group $\mathrm{C}$, and group $\mathrm{D}$, on the basis of their infiltration capability. (Figure 4)

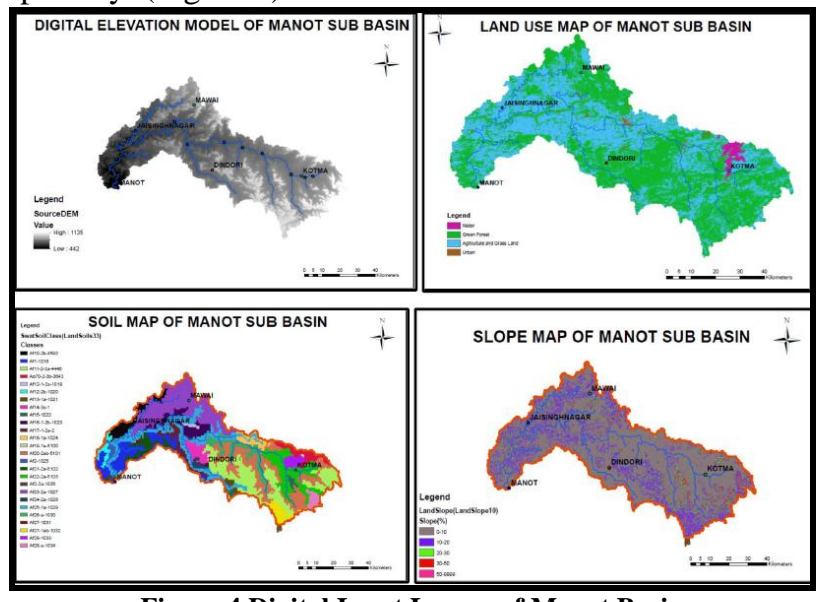

Figure 4 Digital Input Layers of Manot Basin

\section{H. Slope Map}

Longer slope accumulates discharge from a huge region and also results in high flow velocity resulting in increased erosion in a non-linear manner. Steeper slopes produce higher overland flow velocity. Slope map of the Manot basin of the Upper Narmada sub-basin is shown in Figure 4.

\section{Hydrological Response Unit (HRU)}

In the SWAT model, a catchment is distributed into several basins based on slope class, soil type and land-use. Here SWAT divided the basin into 21 sub-basins each of them is the HRUs of the Manot basin which is shown in Figure 5.

\section{MATHODOLOGY}

The SWAT is a distributed model, planned for estimation of impact of basin managing practice in a basin. SWAT pretends the complete hydrologic cycle of a basin. The SWAT model follow MUSLE to evaluate soil loss at the HRU level. The methodology used by SWAT is shown in Figure 6 .

$$
\text { Qs }=11.8\left(\mathrm{Y}_{\text {qpeak }}: A\right) 0: 56 . K . C . P . L S . C F
$$

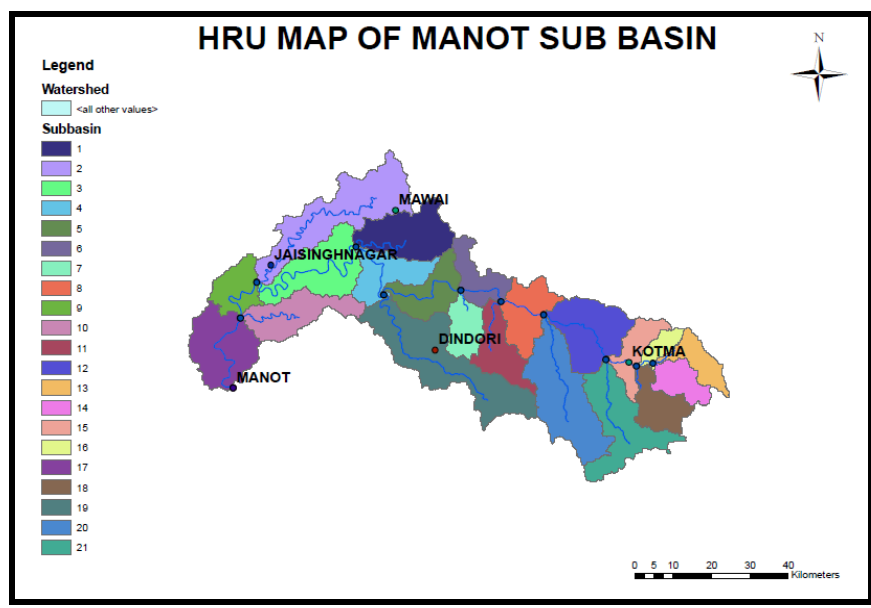

Figure 5 HRU model of Manot Basin

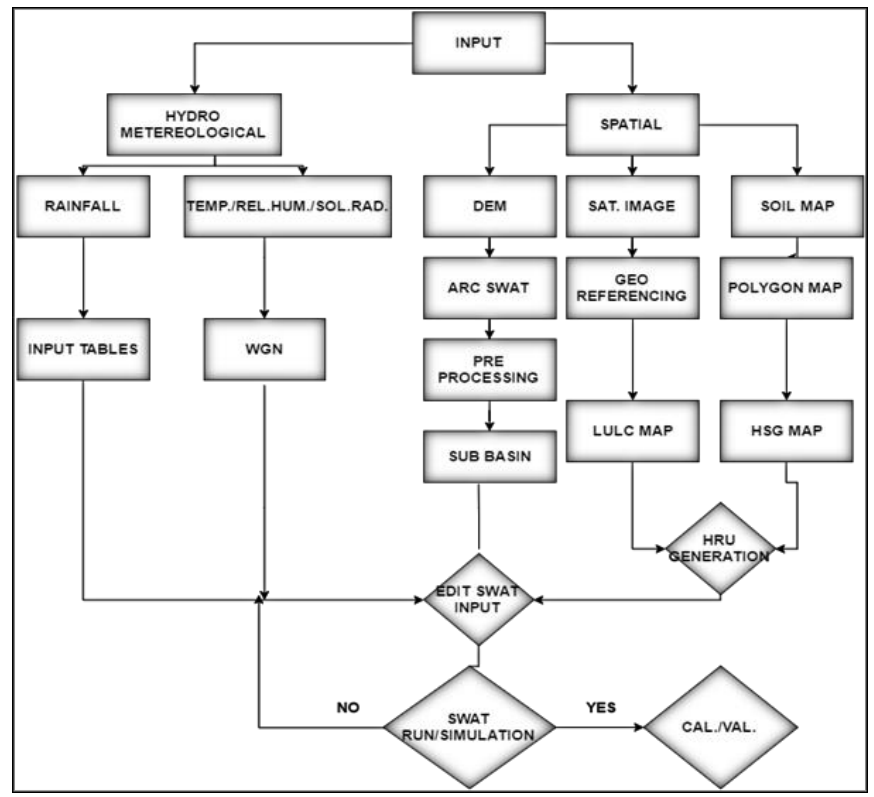

Figure 6 Flow Process of SWAT

Table 3 Criteria for SWAT

\begin{tabular}{|c|c|c|c|}
\hline Criteria & $\begin{array}{c}\text { Default } \\
\text { Value }\end{array}$ & $\begin{array}{c}\text { Calibrated } \\
\text { Value }\end{array}$ & $\begin{array}{c}\text { Faceable } \\
\text { Range }\end{array}$ \\
\hline $\begin{array}{c}\text { Groundwater } \\
\text { Delay (Days) }\end{array}$ & 31 & 80 & $0-500$ \\
\hline $\begin{array}{c}\text { Alpha BF } \\
\text { (Days) }\end{array}$ & 0.048 & 0.15 & $0-1$ \\
\hline GW REVA & 0.02 & 0.2 & $0.02-0.2$ \\
\hline RCHRG-DP & 0.05 & 0 & $0-1$ \\
\hline OV-N & 0.1 & 0.013 & $0.01-30$ \\
\hline ESCO & 0 & 0.5 & $0-1$ \\
\hline CURVE & 67 & 47 & $35-98$ \\
\hline NUMBER & 1.61 & 0.9 & $0.9-2.5$ \\
\hline SOL-BD & 0.15 & 0.4 & $0-1$ \\
\hline SOL-AWC & 43.15 & 20 & $0-2000$ \\
\hline SOL-K & & \multicolumn{2}{c}{} \\
\hline
\end{tabular}

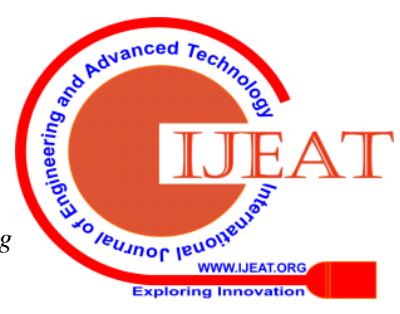




\section{RESULT AND DISCUSSION}

\section{A. Rainfall-runoff for Manot Basin}

SWAT model has been run for 20 years (January, 1989 to December 2008) for the Manot Basin of Upper Narmada River. A skewed normal method option was selected and result was created on a daily scale. Discharge and groundwater flow were summed at the outlet to estimate river flow. The rainfall-runoff curve has been developed and the relation between rainfall and runoff was found to be $\mathrm{Q}=$ 37.92P - 99.441 where $\mathrm{Q}=$ Runoff in $\mathrm{m} 3 / \mathrm{s}$ and $\mathrm{P}=$ rainfall in $\mathrm{mm}$ and coefficient of determination is 0.91 as shown in Figure 7.

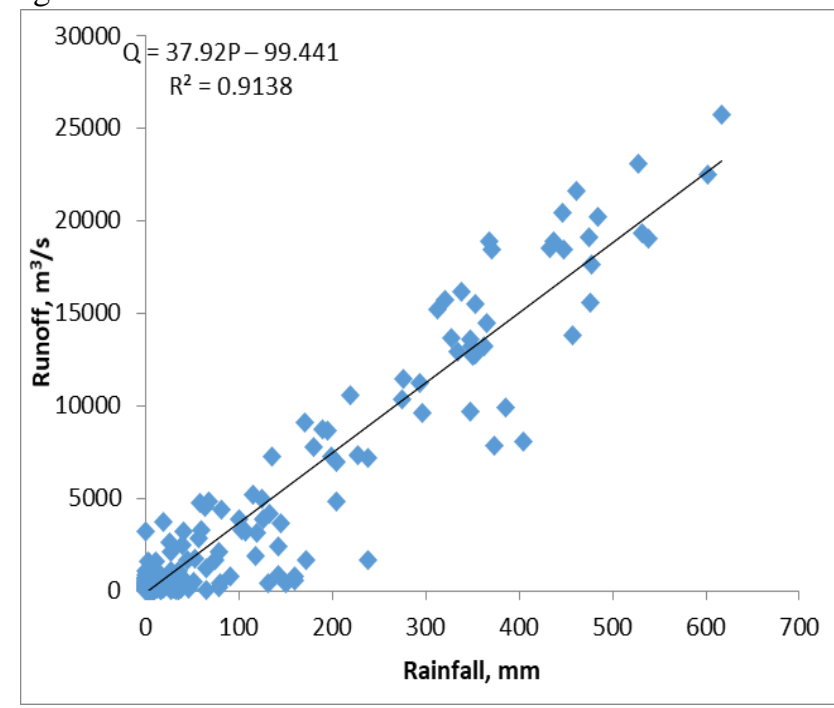

Figure 7 Rainfall-Runoff model for Manot basin.

\section{B. Discharge analysis for Manot basin}

Process parameters (as shown in Table 3) were adjusted with actual streamflow and weather record. To compare the model, predicted and observed runoff hydrographs at the Manot station were compared for twenty years, Figure 8 shows that the predicted hydrographs match with the actual discharge record. Figure 9 shows that the SWAT model simulates well of hydrology for the Manot basin of the upper Narmada river and the coefficient of determination was found to be 0.95 .

\section{Sediment Concentration for Manot basin}

The model was first rectified for discharge and consequently for the sediment concentration. Figure 10 shows a graphical representation of discharge V/S suspended sediment concentration (Sediment rating curve) in power form and the coefficient of determination was found to be 0.901 and the relation between discharge and sediment concentration is Qs=0.013Q1.272

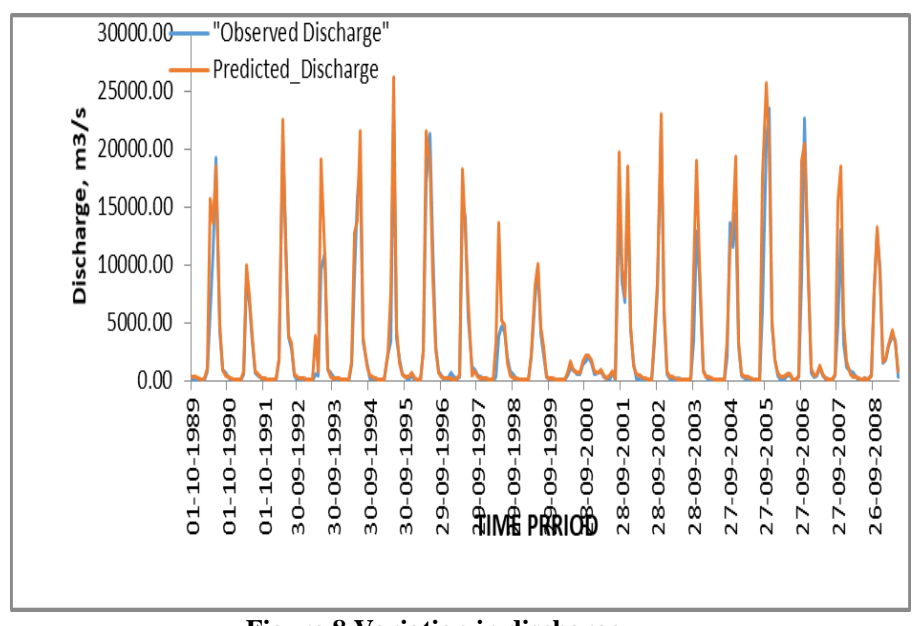

Figure 8 Variation in discharge

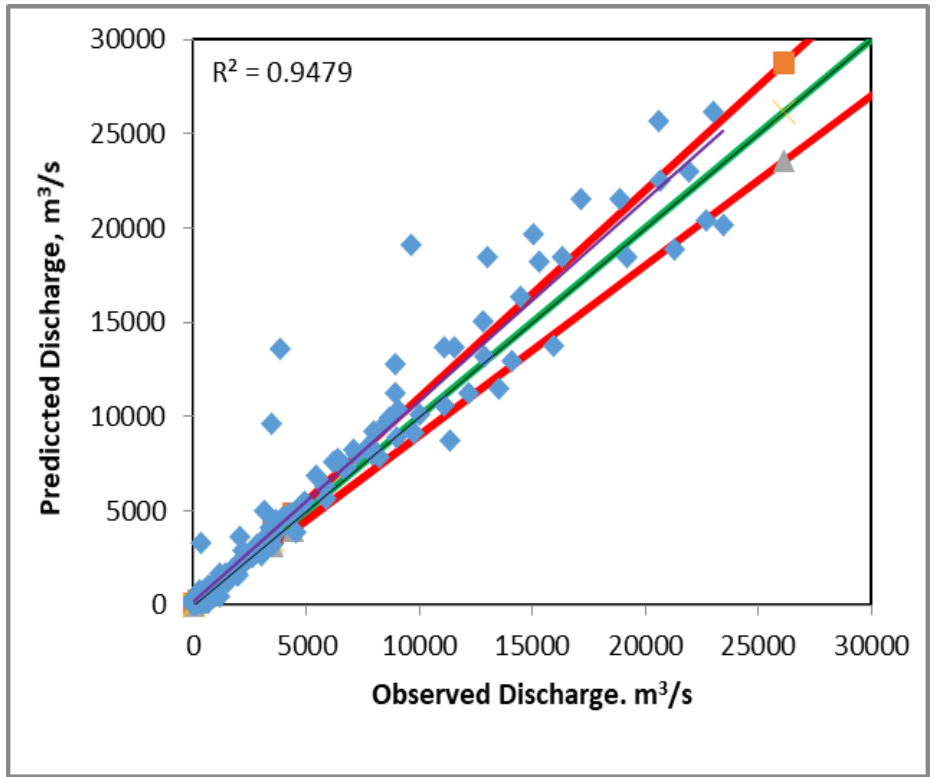

Figure 9 Percentage error is observed and predicted discharge

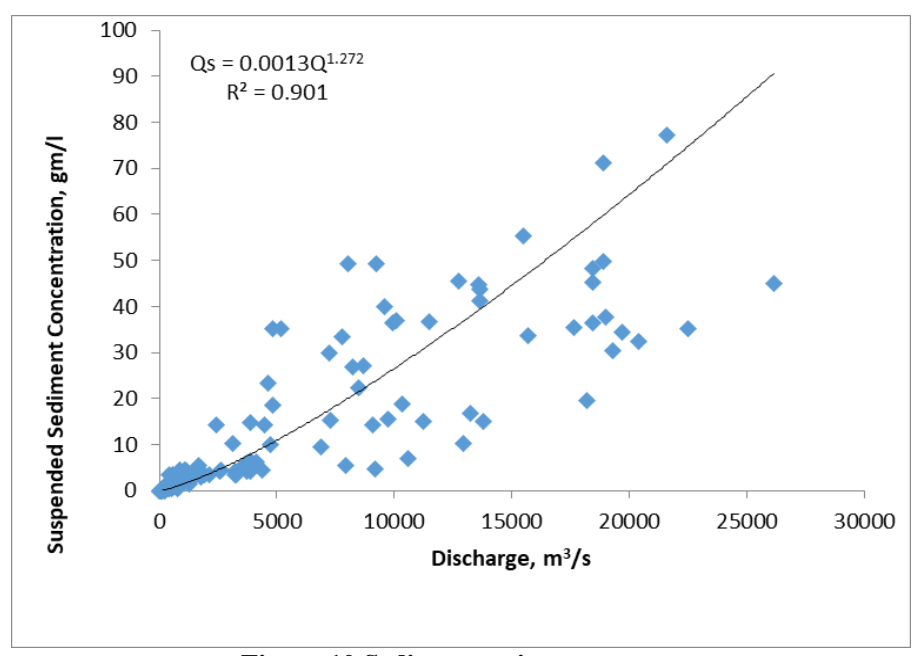

Figure 10 Sediment rating curve

Figure 11 shows the graphical representation of the variation in actual and estimated sediment concentration in gm/l. Figure 12 shows the percentage error of actual and estimated suspended sediment concentration and the coefficient of determination was found to be 0.94 which is acceptable.

Published By:

Blue Eyes Intelligence Engineering

\& Sciences Publication

(C) Copyriaht: All riahts reserved.

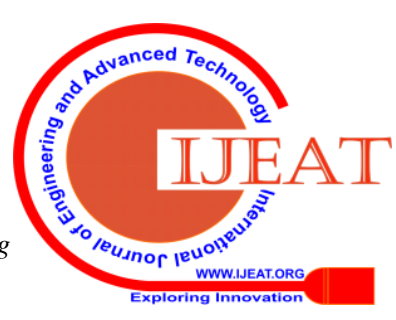




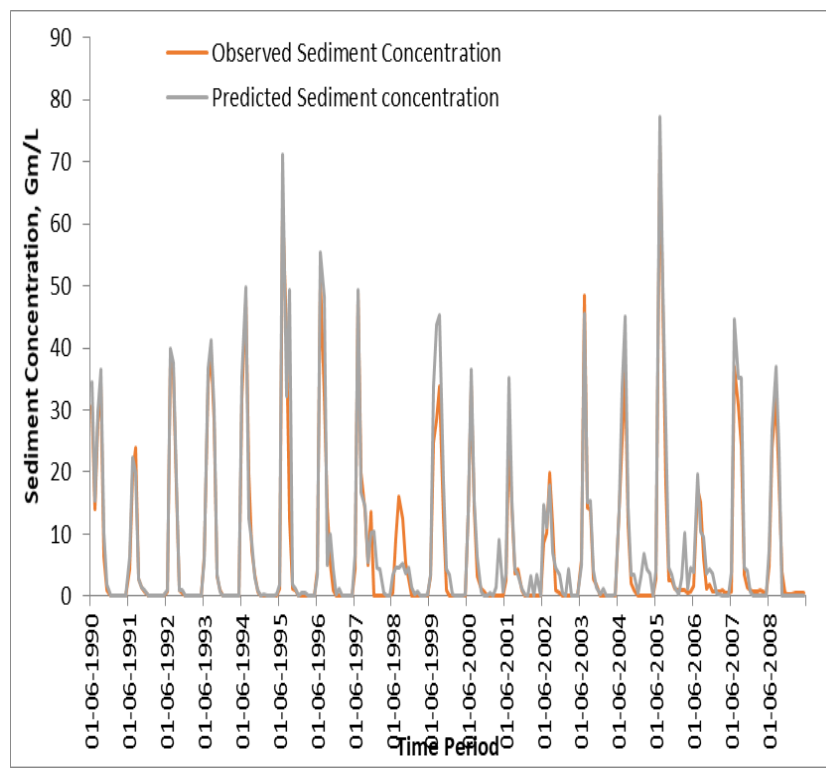

Figure 11 Variation in Observed and Predicted Sediment Concentration

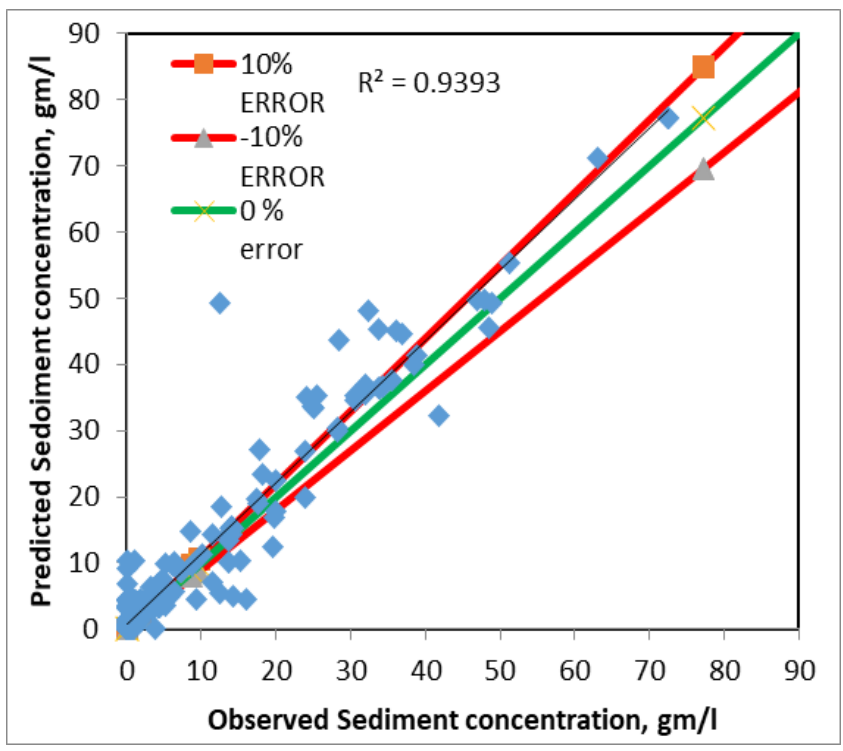

Figure 12 Percentage error in observed and predicted Sediment Concentration, gm/l

\section{Sediment Load analysis for Manot basin}

The model was rectified for discharge, sediment concentration, and consequently for sediment load and sediment yield. Figure 13 shows a graphical representation of the variation of observed and predicted sediment load in tons. Figure 14 shows the percentage error in observed and predicted sediment load and the coefficient of determination was found to be 0.96 .

\section{E. Sediment Yield analysis for Manot basin}

Figure 15 represents the variation in observed and predicted sediment yield. The predicted sediment yield show differences with the actual record because the sediment particles may have deposited in the check dams etc. Average observed and predicted sediment yield was found to be 1.70 and $1.59 \mathrm{~mm}$ respectively. The percentage error or discrepancy ratio has been analysis and the coefficient of determination has been found out to be 0.955 as shown in Figure 16.
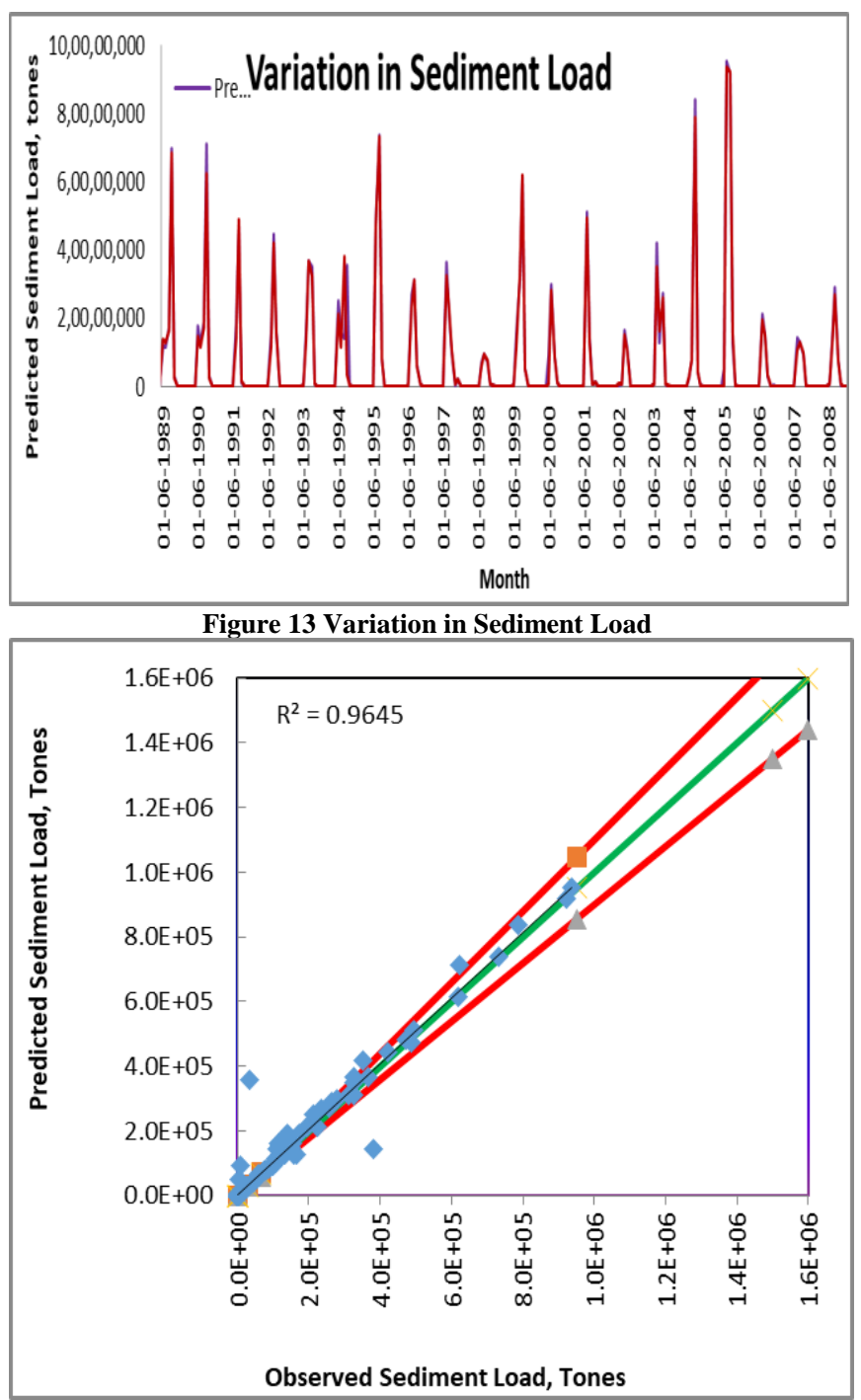

Figure 14 Percentage error is observed and predicted sediment load

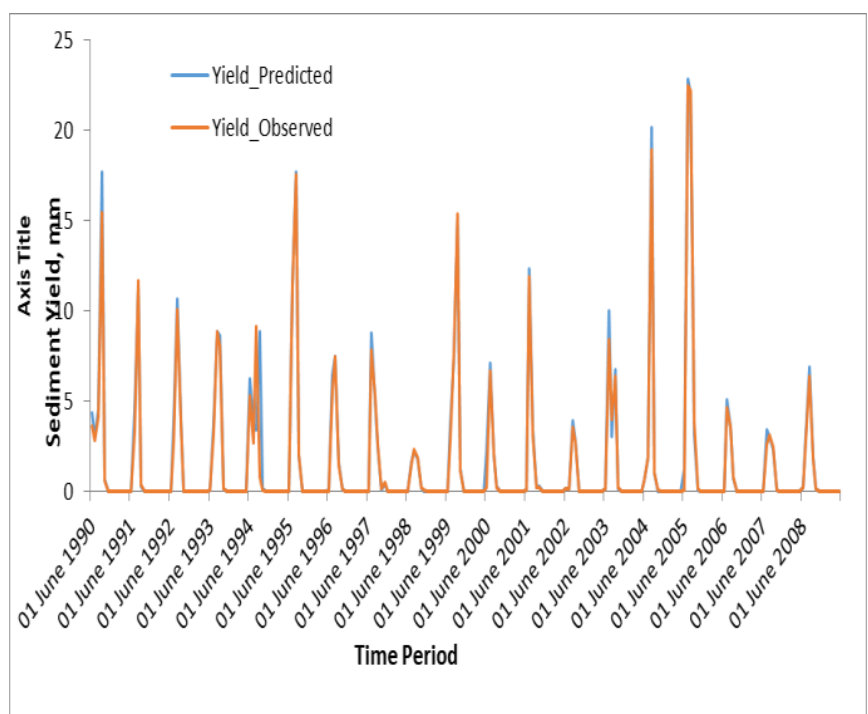

Figure 15 Variation in Sediment Yield

\section{F. Root Mean Square Error (RMSE)}

RMSE shows how much inaccuracy occurs between two records. In other words, it compares predicted and expected value.

Published By:

Blue Eyes Intelligence Engineering

\& Sciences Publication

(C) Copyriaht: All riahts reserved.

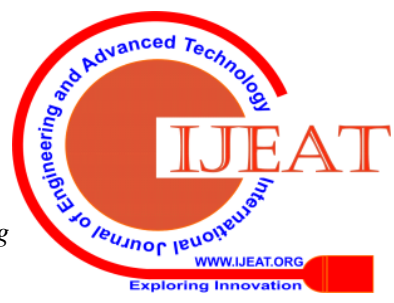




\section{Hydrological Modelling of Sediment Yield of Agr0 -Forestry Watershed}

A smaller value of RMSE indicated closer predicted and observed values are. Table 4 shows RMSE for discharge, sediment concentration, and sediment yield.

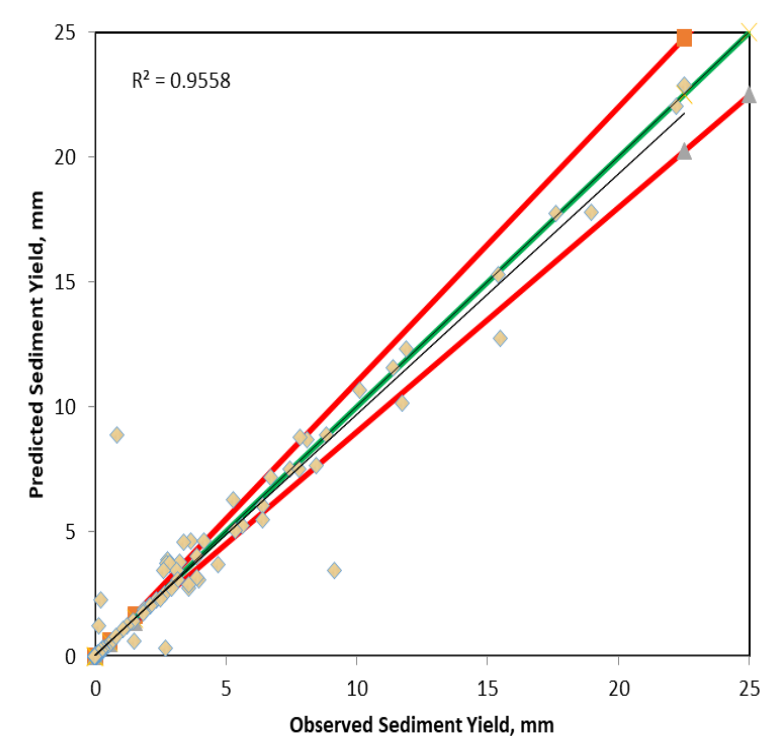

Figure 16 Percentage error in observed and predicted sediment yield.

$$
\text { RMSErTors }=\sqrt{\frac{\sum_{i=1}^{M}\left(\frac{\left.y^{i} i-y^{n}\right)^{2}}{n}\right.}{n}}
$$

Table 4 RMSE for Discharge, Sediment concentration and sediment yield

\begin{tabular}{|c|c|c|c|}
\hline \multirow{2}{*}{ RMSE } & DISCHARGE & $\begin{array}{c}\text { SEDIMENT } \\
\text { CONCENTRATION }\end{array}$ & $\begin{array}{c}\text { SEDIMENT } \\
\text { YIELD }\end{array}$ \\
\cline { 2 - 4 } & 0.33 & 0.17 & 0.27 \\
\hline
\end{tabular}

\section{G. Cohen's kappa coefficient ( $\mathrm{k}$ )}

It is a study that matches the correlation between predicted and observed value. The kappa statistic (or kappa coefficient) is the most commonly used for this purpose[23]. Kappa coefficient can be determined by the equation given by Kappa.

$$
K=(\mathrm{P} 0-\mathrm{Pe}) /(1-\mathrm{Pe})
$$

Where $\mathrm{PO}=$ Predicted value, $\mathrm{Pe}=$ Observed Value

Kappa of 1 states good relation, whereas a kappa of 0 specifies no relation. Table 5 shows the Kappa coefficient for runoff, sediment concentration, and sediment agreement for the observed and predicted results.

Table 5 Kappa Coefficient analysis

\begin{tabular}{|c|c|c|c|}
\hline & Runoff & $\begin{array}{c}\text { Sediment } \\
\text { Concentration }\end{array}$ & $\begin{array}{c}\text { Sediment } \\
\text { Yield }\end{array}$ \\
\hline $\begin{array}{c}\text { Kappa } \\
\text { Coefficient }\end{array}$ & 0.87 & 0.78 & 0.70 \\
\hline
\end{tabular}

\section{CONCLUSION}

In this study, the SWAT model was simulated for the Manot basin, part of the Upper Narmada catchment for the reason to understand the rainfall-runoff process and rainfallsedimentation process. From this study, the following findings can be evaluated. The SWAT model has simulated (period 1989-2008) for prediction of run-off and sediment yield at the reach of the Manot basin. The predicted sediment load at the Manot gauge station for the time-period (1989-2008) is 6670918 Tonnes per year and the observed sediment Load is 6255565 Tonnes per year. In terms of Tones/year/hectare predicted load 14.13 Tonnes/year/Hectare and observed load 15.02 tonnes/year/Hectare respectively. Predicted sediment concentration and predicted sediment concentration at Manot gauging station was found to be $8.81 \mathrm{gm} / \mathrm{l}$ and $7.46 \mathrm{gm} / \mathrm{l}$ respectively. Similarly observed and predicted sediment yield was found to be 1.513 and $1.704 \mathrm{~mm}$ respectively.

The predicted discharge at the exit was compared with the observed discharge for twenty years (1989 to 2008) and the outcome is satisfactory. The coefficient of determination for the discharge was obtained as 0.95, 0.94 for sediment concentration, 0.96 for sediment load, and 0.96 for sediment yield can be considered as a satisfactory value.

Sediment rating curve was derived and the relation between discharge and sediment concentration was found to be Qs=0.013Q1.272 and the coefficient of determination between discharge and sediment load was found out to be 0.90 .

RMSE for the discharge, sediment concentration, and sediment yield were found $0.32,0.27$, and 0.17 respectively. Kappa's coefficient for the discharge, sediment load, and sediment yield was found $0.87,0.78$, and 0.70 respectively. From, above analysis, it can be found that the SWAT model can be capable of simulation of the Upper Narmada river at the Manot basin.

It is found that in the following years, sediment yield decreases. Manot basin is a monitored catchment at an outlet of the basin but ungauged at sub-basin level, therefore a modeling approach to differentiate between the influence of land use and the dams is projected for further research. Various types of research are required to estimate the effects of hydraulic structures on basin hydrology and to predict responses of the basin. First, the local study that observes sediment deposition in the dams. Second, surveys of flow structure, sediment movement, and pattern of deposition in upstream and downstream of dams. The generated data from the surrey can be used to estimate theoretical models of flow over dams which act as walls to sediment movement.

\section{ACKNOWLEDGMENT}

The author highly acknowledges CWC (Central Water Commission, India), NCA (Narmada Control Authority) and IMD (Indian Meteorological Department) for providing data.

\section{REFERENCES}

1. R. Aalto and W. Dietrich, 'Sediment accumulation determined with $210 \mathrm{~Pb}$ geochronology for Strickland River flood plains, Papua New Guinea', p. 8.

2. J. G. Arnold and P. M. Allen, 'AUTOMATED METHODS FOR ESTIMATING BASEFLOW AND GROUNDWATER RECHARGE FROM STREAMFLOW RECORDS', J Am Water Resources Assoc, vol. 35, no. 2, pp. 411-424, Apr. 1999, DOI: 10.1111/j.1752-1688.1999.tb03599.x.

Published By:

Blue Eyes Intelligence Engineering

\& Sciences Publication

(C) Copyriaht: All rights reserved.

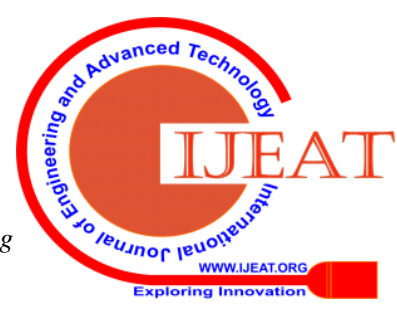


3. E. C. Carson, 'Hydrologic modeling of flood conveyance and impacts of historic overbank sedimentation on West Fork Black's Fork, Uinta Mountains, northeastern Utah, USA', Geomorphology, vol. 75, no. 3-4, pp. 368-383, May 2006, DOI: 10.1016/j.geomorph.2005.07.022.

4. P. Chandra, P. L. Patel, P. D. Porey, and I. D. Gupta, 'Estimation of sediment yield using SWAT model for Upper Tapi basin', ISH Journal of Hydraulic Engineering, vol. 20, no. 3, pp. 291-300, Sep. 2014, DOI: 10.1080/09715010.2014.902170.

5. C. Chutachindakate and T. Sumi, 'SEDIMENT YIELD AND TRANSPORTATION ANALYSIS: CASE STUDY ON MANAGAWA RIVER BASIN', p. 6.

6. M. Demissie, 'Sediment Load during Flood Events for Illinois Streams', Water International, vol. 21, no. 3, pp. 131-137, Sep. 1996, DOI: $10.1080 / 02508069608686505$.

7. T. Dunne, L. A. K. Mertes, R. H. Meade, J. E. Richey, and B. R. Forsberg, 'Geological Society of America Bulletin', Geological Society of America Bulletin, p. 19, 1998.

8. K. A. Gebrehiwot, A. M. Haile, C. M. S. de Fraiture, A. D. Chukalla, and T. G. Embaye, 'Optimizing Flood and Sediment Management of Spate Irrigation in Aba'ala Plains', Water Resour Manage, vol. 29, no. 3, pp. 833-847, Feb. 2015, DOI: 10.1007/s11269-014-0846-1.

9. T. K. Helble, 'Sediment Transport and the Coconino Sandstone: A Reality Check on Flood Geology', vol. 63, no. 1, p. 17, 2011.

10. G. Huang, 'Dual Behavior of Suspended Sediment Concentration in Regulated River', WJM, vol. 01, no. 03, pp. 115-121, 2011, DOI: 10.4236/wjm.2011.13016.

11. M. Karimaee Tabarestani and A. R. Zarrati, 'Sediment transport during flood event: a review', Int. J. Environ. Sci. Technol., vol. 12, no. 2, pp. 775-788, Feb. 2015, DOI: 10.1007/s13762-014-0689-6.

12. U. C. Kothyari, 'SOIL EROSION AND SEDIMENT YIELD MODELLING', ISH Journal of Hydraulic Engineering, vol. 14, no. 1, pp. 84-103, Jan. 2008, DOI: 10.1080/09715010.2008.10514895.

13. R. A. Kuhnle, R. L. Bingner, G. R. Foster, and E. H. Grissinger, 'Effect of land use changes on sediment transport in Goodwin Creek', Water Resour. Res., vol. 32, no. 10, pp. 3189-3196, Oct. 1996, DOI: 10.1029/96WR02104.

14. M. W. Liew and J. Garbrecht, 'HYDROLOGIC SIMULATION OF THE LITTLE WASHITA RIVER EXPERIMENTAL WATERSHED USING SWAT', J Am Water Resources Assoc, vol. 39, no. 2, pp. 413-426, Apr. 2003, DOI: 10.1111/j.1752-1688.2003.tb04395.x.

15. E. V. McDonald, M. R. Sweeney, and A. J. Busacca, 'Glacial outburst floods and loess sedimentation documented during Oxygen Isotope Stage 4 on the Columbia Plateau, Washington State', Quaternary Science Reviews, vol. 45, pp. 18-30, Jun. 2012, DOI: 10.1016/j.quascirev.2012.03.016

16. M. A. Nearing, M. H. Nichols, J. J. Stone, K. G. Renard, and J. R. Simanton, 'Sediment yields from unit-source semiarid watersheds at Walnut Gulch: SEDIMENT YIELDS FROM SEMIARID WATERSHEDS', Water Resour. Res., vol. 43, no. 6, Jun. 2007, DOI: 10.1029/2006WR005692.

17. C. P. Newcombe and D. D. Macdonald, 'Effects of Suspended Sediments on Aquatic Ecosystems', p. 13.

18. A. Prabhanjan, E. P. Rao, and T. I. Eldho, 'Application of SWAT Model and Geospatial Techniques for Sediment-Yield Modeling in Ungauged Watersheds', J. Hydrol. Eng., vol. 20, no. 6, Jun. 2015 DOI: 10.1061/(ASCE)HE.1943-5584.0001123.

19. V. Shivhare, M. K. Goel, and C. K. Singh, 'Simulation Of Surface runoff For Upper Tapi Subcatchment Area (Burhanpur Watershed) Using SWAT', Int. Arch. Photogramm. Remote Sens. Spatial Inf. Sci., vol. XL-8, pp. 391-397, Nov. 2014, DOI: 10.5194/isprsarchives-XL-8-391-2014.

20. T. Tesi et al., 'Flood-driven transport of sediment, particulate organic matter, and nutrients from the Po River watershed to the Mediterranean Sea', Journal of Hydrology, vol. 498, pp. 144-152, Aug. 2013, DOI: 10.1016/j.jhydrol.2013.06.001.

21. X. Zhang, R. Srinivasan, B. Debele, and F. Hao, 'Runoff Simulation of the Headwaters of the Yellow River Using The SWAT Model With Three Snowmelt Algorithms 1, JAWRA Journal of the American Water Resources Association, vol. 44, no. 1, pp. 48-61, Feb. 2008 , DOI: 10.1111/j.1752-1688.2007.00137.x.

22. H. M., 'A STUDY ON SOIL EROSION AND ITS IMPACTS ON FLOODS AND SEDIMENTATION', IJRET, vol. 03, no. 15, pp. 443-451, May 2014, DOI: 10.15623/ijret.2014.0315086.

23. A. J. Viera and J. M. Garrett, 'Understanding Interobserver Agreement: The Kappa Statistic', Family Medicine, p. 4.

\section{AUTHORS PROFILE}

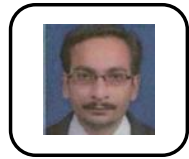

Bankim R Joshi, Presently research scholar in Civil Engineering Department, Sardar Vallabhbhai National Institute of Technology, Surat Gujarat, India-395007.

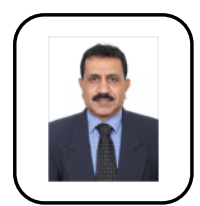

Dr. S. M. Yadav, Professor, Civil Engineering Department, Sardar Vallabhbhai National Institute of Technology, Surat Gujarat, India-395007. He is having a teaching experience of more than thirty years. His research interests are Flood Modelling, Flood Risk Assessment and Management, Real-time Flood Forecasting, Climate Change, Remote Sensing and Geographic Information System, Fluvial Hydraulics and Application of Soft Computing Techniques in WRE. He has completed nearly 50 consultancy projects. Dr. Yadav has been working as an expert for ongoing dredging work in the Rivers of central India like Ghaghara, Ganga, Gandak and Rapti as a flood mitigation measures. Dr. Yadav has conducted several training programs on flood modelling and analysis. He has received the prestigious Hariom Asharam Prerit award for his outstanding research contribution. He has received several best paper awards at national and international conferences. He has been the recipient of AuSAID funding thrice for presenting his research work at the International River Symposium. He has presented his research work for ten international conferences held at various locations of the world. He has authored one book. He has guided four doctoral scholars. Eight scholars are perusing their research under his guidance. He has guided around fifty postgraduate dissertation work. Delivered more than fifty expert lecture in International and National Institutes/ Colleges/ Industries. Published more than a hundred papers in an international/ national journals and conferences. He is a contributing member and lead member of several technical committees and served as a thesis committee member for several national doctoral dissertations. He is Charter Civil Engineer, IE, India. He is a Fellow of Institute of Engineers India and Indian Society of Hydraulics, Pune.

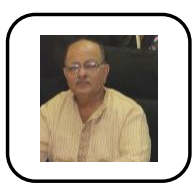

Dr. B. K. Samtani, Retd. Professor in the Department of Civil Engineering at Sardar Vallabhbhai National Institute of Technology, Surat was taught subjects like Fluid Mechanics, Advanced Fluid Mechanics, Water Resources Engineering, Hydraulics of Alluvial River, Open Channel Flow, Water Resources System, Hydro Power Engineering at UG and PG level. Prof. Samtani has a vast experience of 35 years in the field of academics, research and consultancy. Prof. Samtani has undertaken 12 research works which have 13 citations and 313 reads. Prof. Samtani has been the Head of Civil Engineering Department from 2008-11 and also was Dean (Examination) for more than 3 years from 2005-08. Prof. Samtani has successfully supervised $3 \mathrm{PhD}$ candidates, and currently supervising $3 \mathrm{PhD}$ in full-time category and 3 in the part-time category. He is the life-member of more than 5 well known technical society.

Published By:

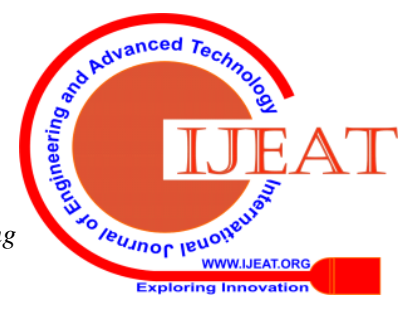

